\title{
Towards the conservation of Borneo's freshwater mussels: rediscovery of the endemic Ctenodesma borneensis and first record of the non-native Sinanodonta lauta
}

\author{
Alexandra Zieritz, et al. [full author details at the end of the article]
}

Received: 4 September 2019/Revised: 3 March 2020 / Accepted: 30 March 2020/

Published online: 13 April 2020

(C) The Author(s) 2020

\begin{abstract}
The freshwater mussel fauna of Borneo is highly endemic, with at least 11 species being unique to that island. Most of these species have not been recorded for at least 50 years owing to a lack of sampling effort and large-scale habitat destruction and degradation. Surveys conducted in 2016 across much of Malaysian Borneo failed to locate four out of five native species historically recorded in the study area. The present study aimed to determine the diversity and distribution of freshwater mussels of Brunei and adjacent Limbang Division, Malaysia. In 2018, we conducted interviews with locals, recorded environmental data and surveyed mussels at 43 sites, and conducted interviews at a further 38 sites. Only one population of native mussels, i.e. Ctenodesma borneensis, was found in a small tributary of the Limbang River situated in a patch of intact rainforest, representing the first record of this Bornean endemic genus since 1962. In addition, Sinanodonta lauta was found in a pond in Lawas district, representing the first record of this species outside its native East Asian distribution. Our data suggest that $C$. borneensis can sustain populations in relatively undisturbed habitats and is likely to have suffered population losses across northern Borneo. The first molecular phylogenetic analysis (COI $+28 \mathrm{~S})$ including an endemic Bornean freshwater mussel genus revealed that Ctenodesma is phylogenetically divergent from all other previously sampled lineages, rendering it a particularly valuable conservation target.
\end{abstract}

Keywords Endemic species - Freshwater biodiversity - Non-native species - Threatened species $\cdot$ Tropics $\cdot$ Unionida

Communicated by Angus Jackson.

Electronic supplementary material The online version of this article (https://doi.org/10.1007/s10531-02001971-1) contains supplementary material, which is available to authorized users. 


\section{Introduction}

Freshwater mussels (Unionida) are one of the most threatened animal groups, with $45 \%$ of assessed species being listed as near-threatened, threatened or extinct in the IUCN Red List (IUCN 2019). Causes for the steep declines in diversity and abundance of these filterfeeders, which inhabit the bottom of freshwater habitats across the globe, include direct habitat loss and degradation due to flow modification and pollution, as well as indirect pressures on the catchment, such as increased sedimentation following deforestation (Dudgeon et al. 2006; Lopes-Lima et al. 2018). As mussels fulfil crucial ecosystem services, including water purification, nutrient cycling and food provision, their decline can be detrimental to ecosystems and people, particularly in developing countries (Chowdhury et al. 2016; Vaughn 2018; Zieritz et al. 2018a, 2019). Taxon-based conservation efforts require a sound understanding of the diversity, distribution, ecology and threats to populations, but this information is lacking for most Southeast Asian freshwater mussels (Lopes-Lima et al. 2018; Zieritz et al. 2018b). As a result, the conservation status of 53\% of the 135 freshwater mussel species present in Southeast Asia (Zieritz et al. 2018b) has either not been assessed to date or is currently classified as "data deficient" by the IUCN (IUCN 2019).

In regions with high rates of endemism, loss of habitat will lead to particularly high rates of species loss (Myers et al. 2000). The freshwater mussel fauna of Borneo is diverse and highly endemic, with 3-4 of its 10 genera and 11-13 of its 17 species being unique to the island (Table 1; Zieritz et al. 2018b; Graf and Cummings 2019). However, our understanding of the Bornean freshwater mussel assemblage is very limited and most species have not been recorded for several decades (Zieritz and Lopes-Lima 2018). As a result, none of Borneo's endemic taxa have been included in any molecular phylogenetic context nor have any of them been the subject of any type of conservation assessment (Table 1). Whilst to some extent, this severe lack of knowledge is a result of the lack of targeted surveys, it also may reflect that Bornean freshwater mussels have become more rare and, in some cases, potentially extinct in the course of intense deforestation and habitat destruction since the 1960s (Brook et al. 2003; Iwata et al. 2003; Gaveau et al. 2014). A recent survey across 72 sites and 21 river basins from Sarikei Division in western Sarawak to Kudat Division in eastern Sabah (Fig. 1) failed to locate four out of five native species with historical records from the study area (Zieritz et al. 2018c). Occurrence of the only native species recovered, Rectidens sumatrensis, was shown to be strongly negatively associated with the proportion of anthropogenic land cover, and organic and inorganic pollution. In contrast, the non-native invasive species Sinanodonta cf. woodiana showed positive associations with human influence and is now the most widespread and common freshwater mussel in the study area.

Although a considerable step forward towards understanding northern Borneo's freshwater mussel diversity, distribution and conservation status, Zieritz et al.'s (2018c) dataset did not include any sites from Brunei or the adjacent Limbang Division of Sarawak. Brunei was identified as an area of particular importance for future surveys because it has retained much of its primary forest (Bryan et al. 2013) and as such, may serve as refuge for Borneo's endemic mussels. However, records of freshwater mussels from Brunei are confined to a small number of museum lots of the Bornean endemic Pressidens exanthematicus with the general location "Brunei" and dating back to before or shortly after the turn of the nineteenth century (i.e. SMF 13878, SMF 13881, UMMZ 110138, UMMZ 110251, USNM 346982; Graf and Cummings 2019). Considering that today's Limbang 


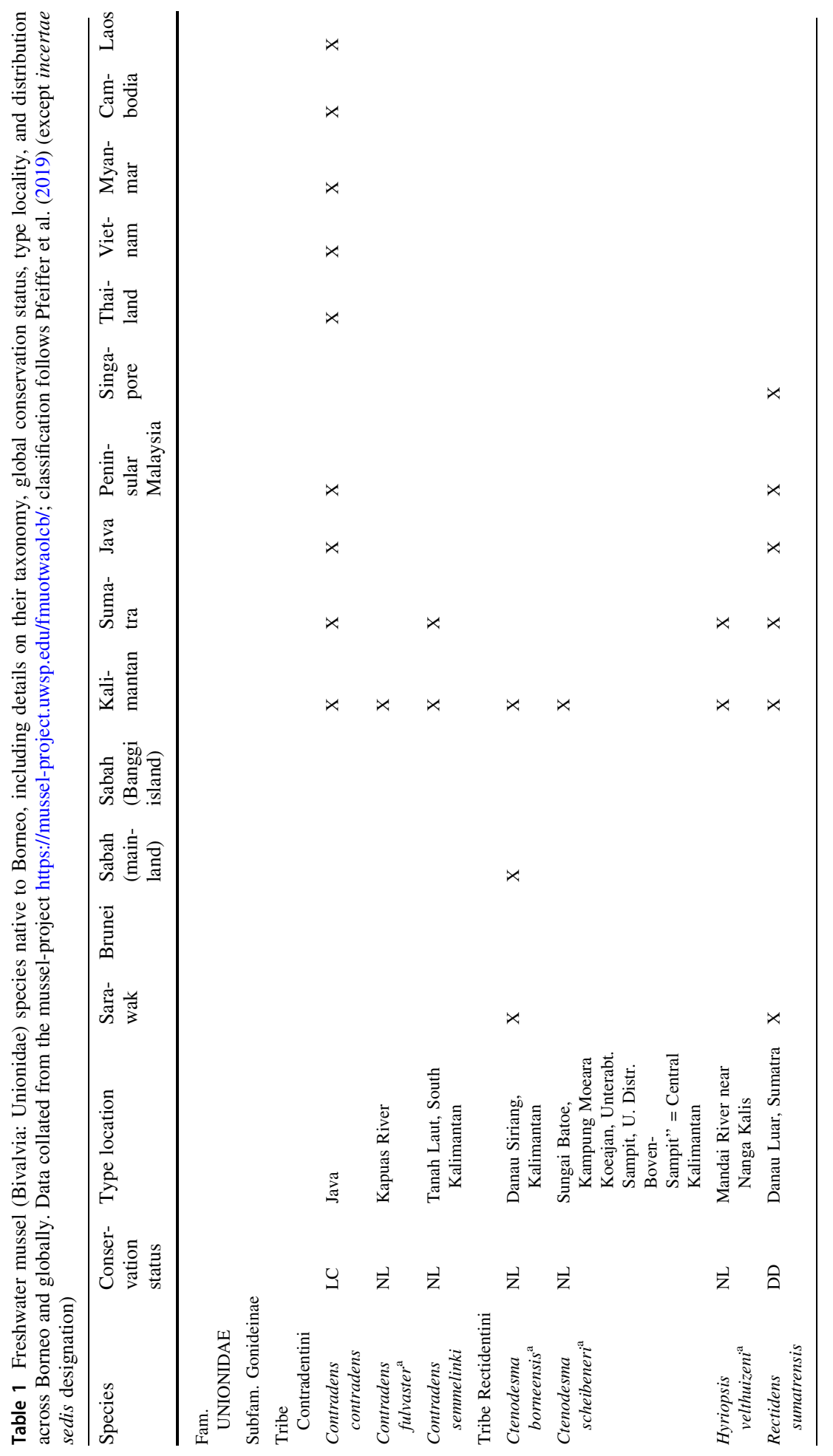




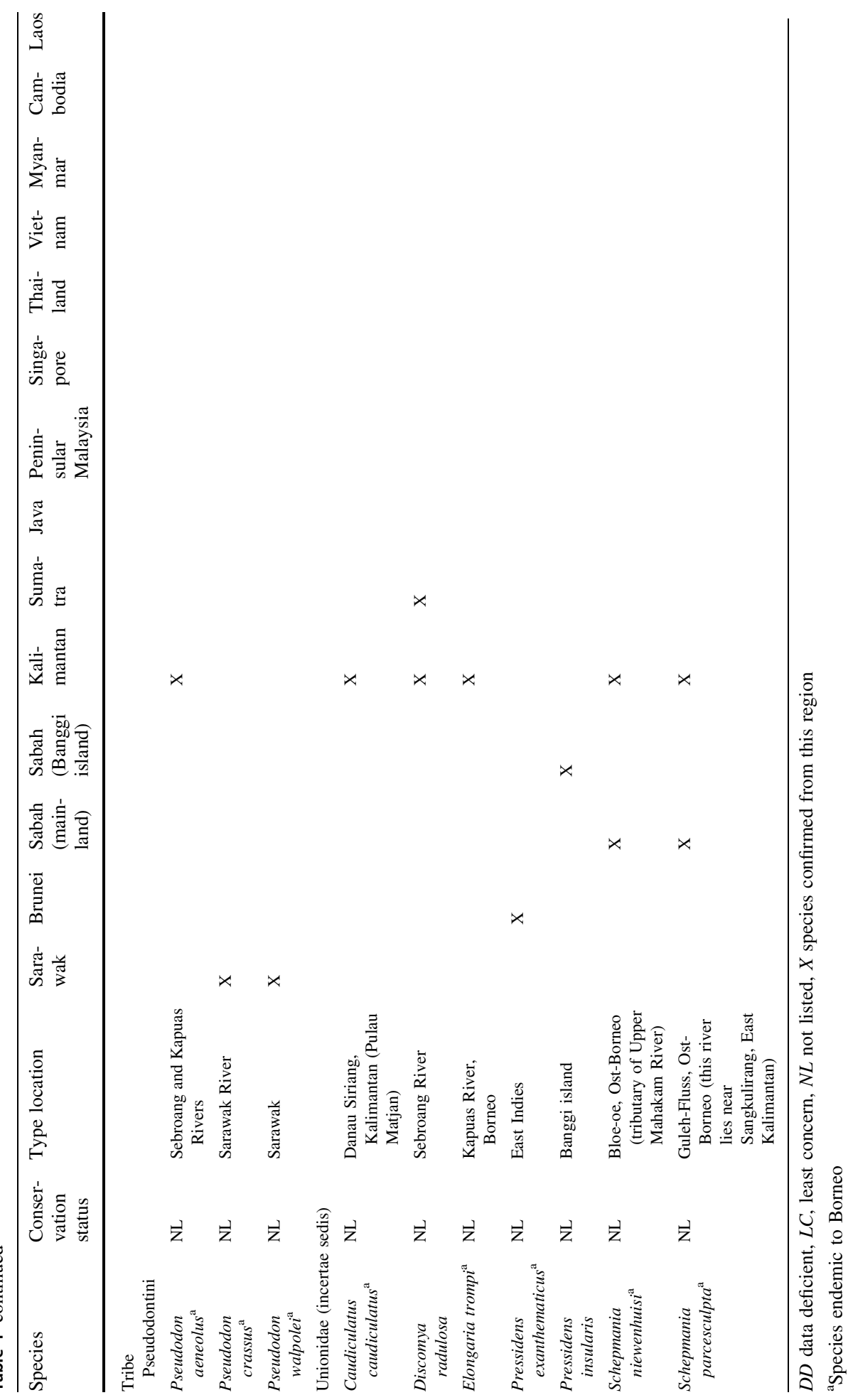




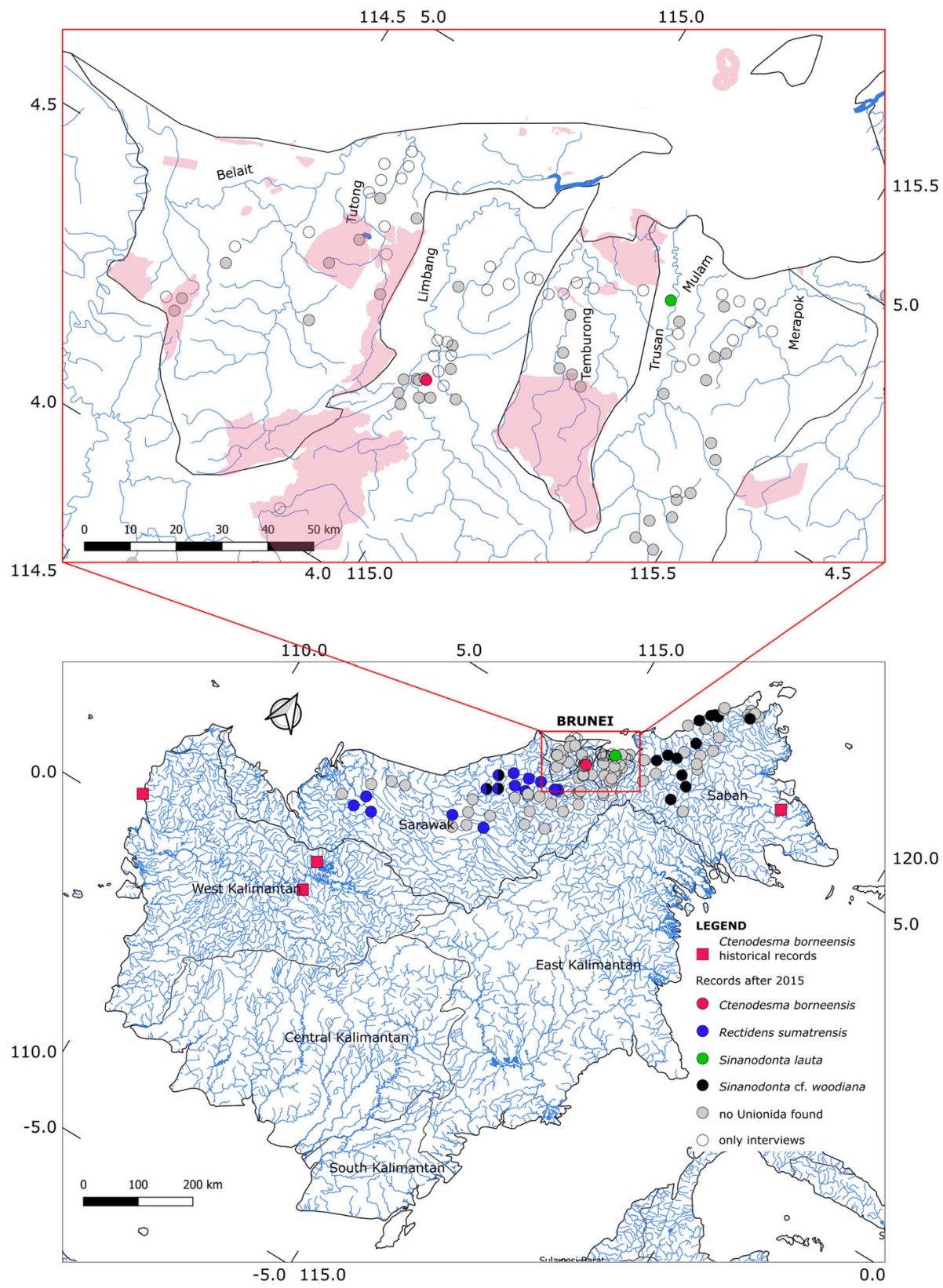

Fig. 1 Location of sites in Borneo surveyed for freshwater mussels (Unionida) from 2015 to 2018 (circles) and of historical records of Ctenodesma borneensis (squares). Inset framed in red shows study area and sites surveyed in the course of the present study, with protected areas highlighted in light red

Division, Sarawak, Malaysia, was lost from Brunei to Malaysia in 1890, some or all of these "Brunei" specimens may therefore actually originate from Limbang. In addition, we are aware of two historical records of R. sumatrensis from the Limbang River in Limbang 
Division (BMNH 39-4-27-57-60, UMMZ 110534), also dating from before or shortly after the turn of the nineteenth century.

The present study aims to determine the diversity and distribution of freshwater mussels in Brunei and Limbang Division through targeted surveys across all the main river basins in the study region. The phylogenetic position of the only Bornean endemic genus sampled (Ctenodesma) was then recovered by molecular phylogenetic analysis. Results of this work are subsequently discussed in light of previous work in Malaysian Borneo to draw conclusions on the current state of freshwater mussel biodiversity in northern Borneo.

\section{Methods}

\section{Study area}

The study area covered about $13,000 \mathrm{~km}^{2}$, spanning the Kingdom of Brunei and Limbang Division, Sarawak (Fig. 1). The area is characterised by a tropical rainforest climate and is dominated by shale, siltstone and sandstone deposits, with some limestone in the upper reaches of the Limbang River (Mathew et al. 2016). It is located within the freshwater ecoregion of Northwestern Borneo, which features a diverse and highly endemic fish fauna (Abell et al. 2008; Rahim 2012; Sulaiman et al. 2018). The area includes several protected areas, most notably the National Parks of Tasek Merimbun and Ulu Temburong in Brunei, and Gunung Mulu and Gunung Buda in Limbang Division (Fig. 1).

\section{Field surveys}

Field surveys were conducted in the dry season, when water levels are lowest and access to mussels is therefore optimal, in March, April and July 2018. A total of 81 sites were surveyed (inset in Fig. 1), situated in the basins of the Belait, Tutong, Limbang, Temburong, Trusan, Mulam and Merapok rivers (from west to east) (Fig. 1, Online Resource 1). Sites included a range of freshwater habitats, from small, shallow streams $(<1 \mathrm{~m}$ width), to large lowland rivers ( $>30 \mathrm{~m}$ width), as well as standing water bodies such as man-made ponds. Surveys were completed in two stages, i.e. (1) interviews and (2) physical surveys. Access to the site was not deemed safe due to the presence of Estuarine Crocodiles (Crocodylus porosus) at 38 sites, which are therefore limited to data from interviews (empty circles in inset of Fig. 1); both interviews and physical surveys were conducted at 43 sites (full circles in inset of Fig. 1).

At each site, covering about $100 \mathrm{~m}$ river length, we initially approached local people living or operating in the vicinity of the river (e.g. fishermen) to ask about safe access to the river and the presence of freshwater mussels (see Online Resource 2 for a list of questions put to interviewees). Whenever possible, at least three individuals from diverse demographic groups (age, sex and ethnicity) were interviewed informally at a locality of their choice (usually outside their house or on the river bank) to minimise disruption to them and thus maximise willingness to share their knowledge. Interviewees were thereby shown pictures of the freshwater mussel species previously recorded from northern Borneo. Where access was deemed safe (i.e. absence of crocodiles and river accessible with minimal risk of snake bites or falls), we surveyed for mussels by hand, net and rake following the same protocol as described in Zieritz et al. (2018c). Where mussels were found, voucher specimens and tissue snips were collected and preserved in absolute 
ethanol and deposited at the Research Collection of the Universiti Malaysia Sarawak (UNIMAS). Except for vouchers, all other specimens were returned to their habitat.

\section{Measurement of environmental parameters}

Several water quality parameters known to affect mussel distribution (see Zieritz et al. 2016; Zieritz et al. 2018c and references therein) were collected at each site: (1) pH, (2) dissolved oxygen (DO), (3) temperature and (4) conductivity were measured in situ using EUTECH pH 5 + (Eutech Instruments Europe BV, Nijkerk, Netherlands), and EXTECH instruments (Extech Instruments Inc., Nahua, NH, USA) SDL150, SDL100 and EC210, respectively. In addition, $300 \mathrm{ml}$-water samples were collected, of which at least $200 \mathrm{ml}$ were filtered through a Whatman GF/C filter on the evening of the day of collection and $25 \mathrm{ml}$ were immediately processed for analysis of concentrations of (5) total phosphorus (TP) by adding sulfuric acid. GF/C filters were folded, individually wrapped in labelled tin foil and stored together with water samples in the dark on ice whenever possible. Concentrations of (6) soluble reactive phosphorus (SRP) and (7) total ammoniacal nitrogen (TAN) were determined in the laboratory using standard spectrophotometric/colorimetric methods (Lorenzen 1967; Mackereth et al. 1989). (8) Organic matter (OM) concentrations of suspended solids were determined as $\left(\mathrm{W}_{\mathrm{bi}}-\mathrm{W}_{\mathrm{ai}}\right) / \mathrm{V}$, where $\mathrm{W}_{\mathrm{bi}}$ is weight $[\mathrm{mg}]$ of $\mathrm{GF} / \mathrm{C}$ filters and residue after drying at $105{ }^{\circ} \mathrm{C}$ for $24 \mathrm{~h}, \mathrm{~W}_{\mathrm{ai}}$ is weight [mg] of $\mathrm{GF} / \mathrm{C}$ filters and residue after $4 \mathrm{~h}$ at $550{ }^{\circ} \mathrm{C}$, and $\mathrm{V}$ is the volume of water filtered [1]. Concentrations of (9) calcium $\left(\mathrm{Ca}^{+}\right)$and $(10)$ potassium $\left(\mathrm{K}^{+}\right)$ions were determined through ion chromatography (IC) analysis using a Metrohm Basic 792 ion chromatography system (Metrosep A Supp 4-250 column, with $1 \mathrm{mmol}$ sodium bicarbonate and $3.2 \mathrm{mmol}$ of sodium carbonate eluent

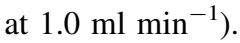

\section{Species identification, and morphological and phylogenetic analysis}

Collected specimens were identified to species level through an integrative morphologicalmolecular approach. DNA was extracted from three specimens of each population using Macherey-Nagel Nucleo-Spin Tissue Kit following the manufacturer's instructions. Cytochrome c oxidase subunit I (COI) mitochondrial DNA was amplified and sequenced in both directions from all extracts using primers and protocol detailed in Zieritz et al. (2016). For native species, we additionally sequenced $28 \mathrm{~S}$ ribosomal DNA using primers and protocol detailed in Lopes-Lima et al. (2017). Sequences were cleaned up in program MEGA X (Kumar et al. 2018) and deposited on Genbank under Accession Numbers MN900788-900794 and MN902292-902301.

Initial BLAST results of the novel Ctenodesma sequences suggested phylogenetic affinities to representatives of the subfamily Gonideinae (sensu Pfeiffer et al. (2019)), especially members of the tribes Rectidentini and Contradentini. We designed our taxon sampling to recover the phylogenetic position of Ctenodesma by sampling all representative species of the tribes Rectidentini and Contradentini available on Genbank, as well as representatives of the other tribes of the Gonideinae (Table 2). Molecular matrices were aligned using ClustalW v. 2.1 (Larkin et al. 2007). PartitionFinder2 v 2.1.1 (Lanfear et al. 2017) was used to find the best partition scheme and Generalised time-reversible (GTR) model of nucleotide evolution using the AICc and greedy search algorithm (Lanfear et al. 2012). Maximum-Likelihood (ML) searches were then conducted in IQ-TREE v 1.6.10 (Nguyen et al. 2015) with an initial tree search followed by 10 independent runs and 


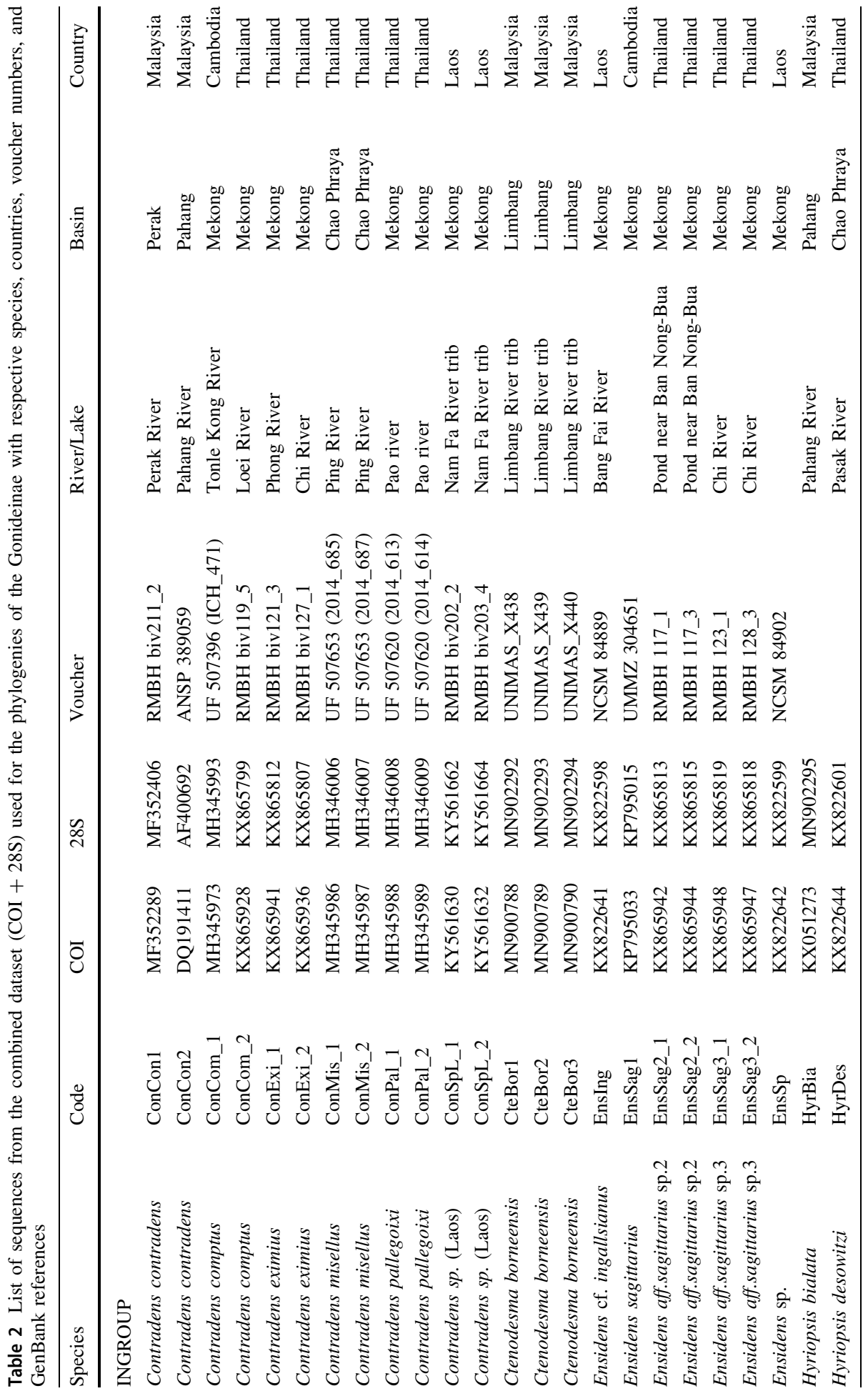




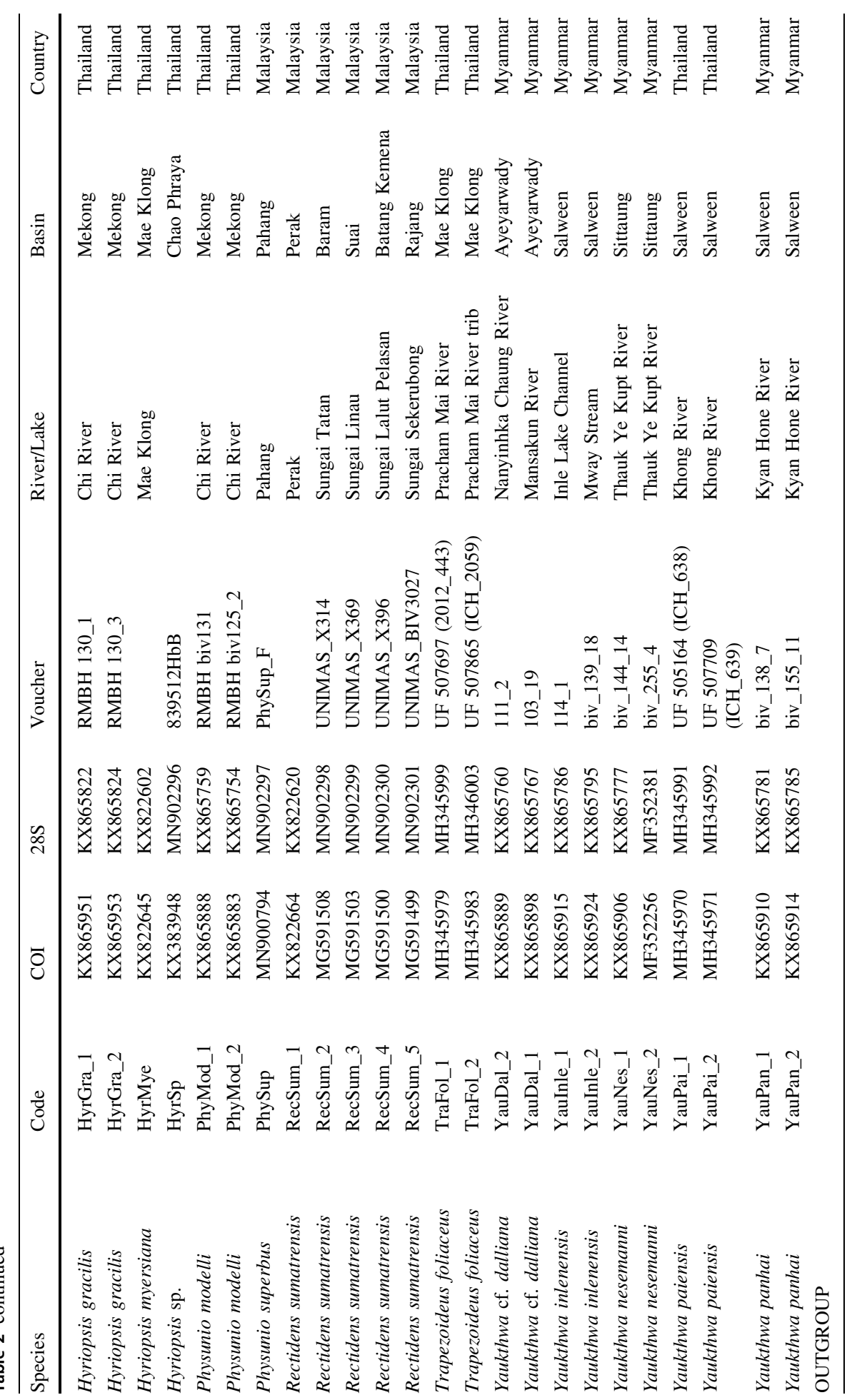




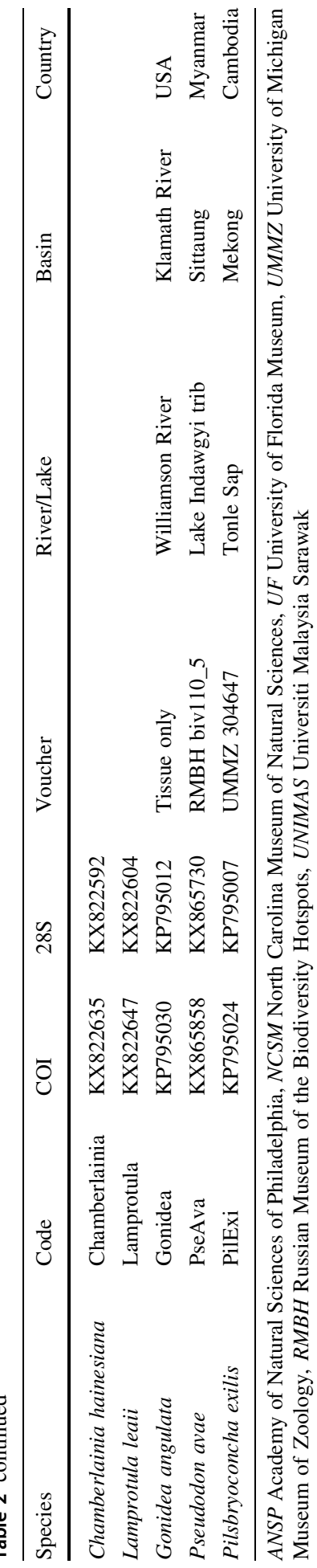

Springer 
10,000 ultrafast bootstrap replicates using the best codon partitioning scheme and model of nucleotide evolution. Bayesian inference (BI) analysis was performed using MrBayes v 3.2 (Huelsenbeck and Ronquist 2001; Ronquist et al. 2012) using the best codon partitioning scheme and model of nucleotide evolution with $20 \times 10^{6}$ generations sampling every 1000 generations for a total of 20,000 trees with a burnin of 5000. Convergence of the two runs was monitored by the average standard deviation of split frequencies, the potential scale reduction factor (PSRF) and the effective sample size (ESS) of the estimated parameters.

Ctenodesma specimens were analysed for their morphology and anatomy, which included visual examination of shell shape, colour and sculpture, as well as siphons and marsupia under a light microscope. Shell dimensions were measured using sliding calipers to the nearest $0.1 \mathrm{~mm}$.

\section{Results}

\section{Diversity and distribution}

Out of the 43 sites where both interviews and physical surveys were conducted, only one population of native mussels was found in a tributary of the Limbang River near the village of Kuala Medalam (alternative spelling Mendalam; Fig. 2). The species was identified as Ctenodesma borneensis by morphological characters. The species is small and elongated elliptical (Haas 1969), with dimensions of collected specimens being 4.3, 4.8 and $5.0 \mathrm{~cm}$ in length, and 2.0, 2.4 and $2.5 \mathrm{~cm}$ in height (Fig. 2a). Shells are coloured yellow-greenish to brown with rays and exhibit fine, irregular zig-zag sculpture. Umbos were heavily eroded in all specimens. Inhalant siphons exhibit one row of papillae (Fig. 2b). The one gravid specimen we collected exhibited glochidia in all four demibranchs (tetragenous).

$\mathrm{COI}$ and $28 \mathrm{~S}$ sequences generated for the three specimens were identical (Genbank Accession numbers in Table 2). They were highly divergent from available sequences on Genbank, with the closest match being Sinoyriopsis cumingii with $86.3 \%$ similarity for COI, and Hyriopsis sp., Ensidens sp. and R. sumatrensis with $97.9-98.1 \%$ for $28 \mathrm{~S}$.

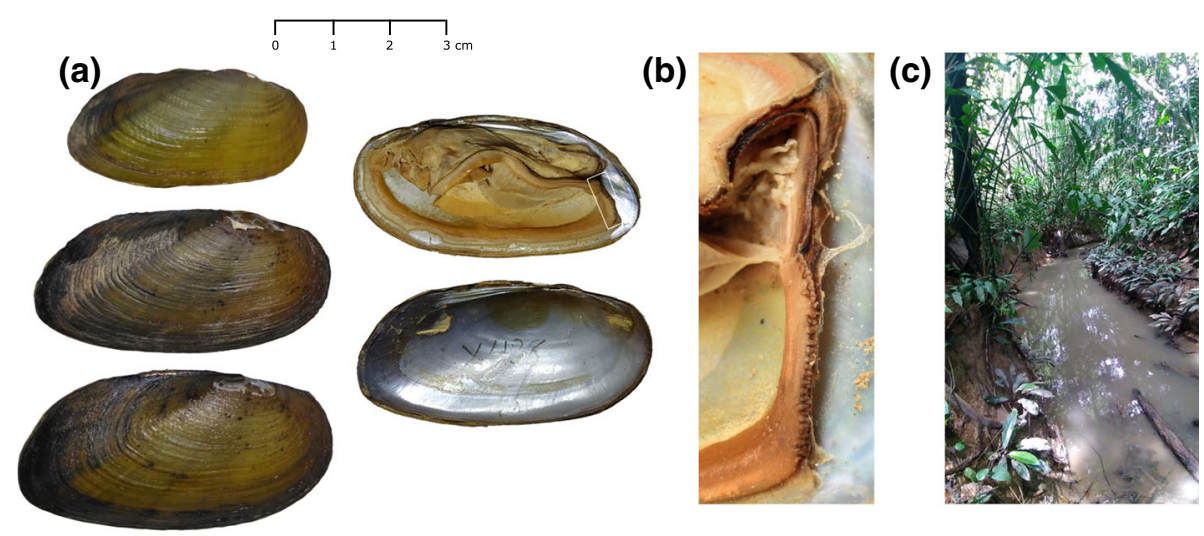

Fig. 2 a Exterior and interior view of the three Ctenodesma borneensis specimens collected in 2018, b detailed picture of siphons (white rectangular area in Fig. 1a), and c picture of the sampling site in a tributary of the Limbang River, Sarawak, Malaysia 


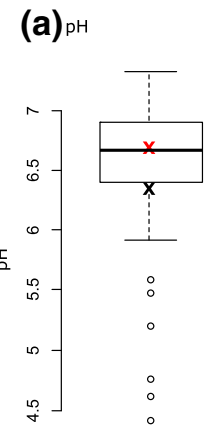

(f) SRP

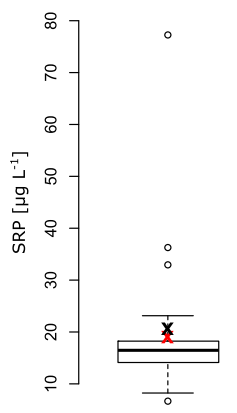

(b) $\triangleright \circ$

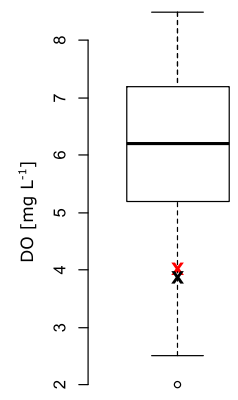

(g) ${ }^{\mathrm{TP}}$

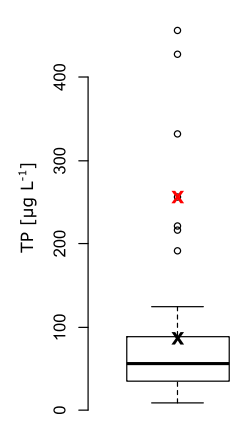

(c) Temperature

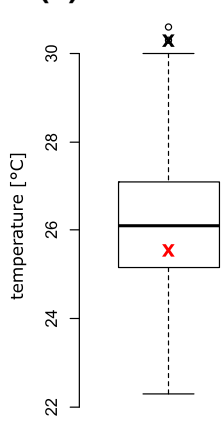

(h) organic matter

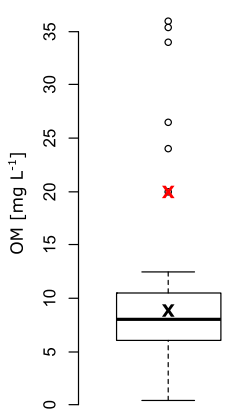

(d) Conductivity

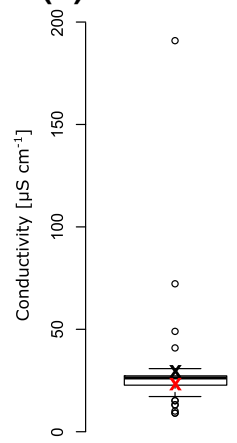

(e) TAN
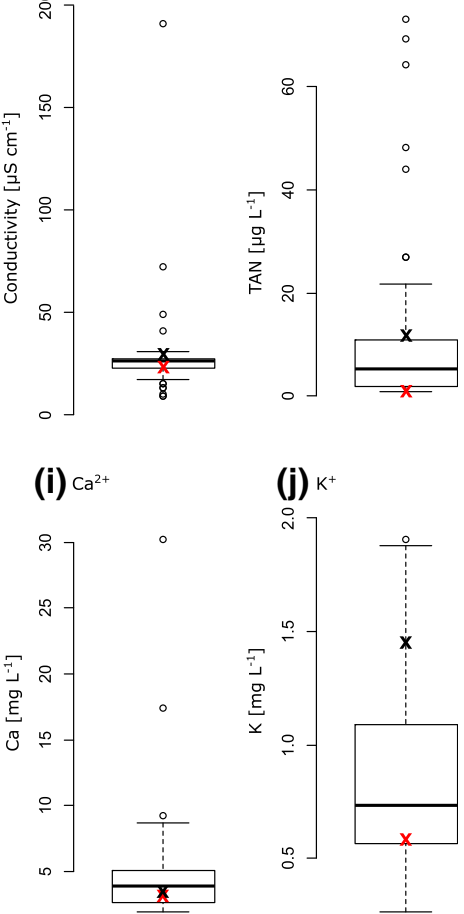

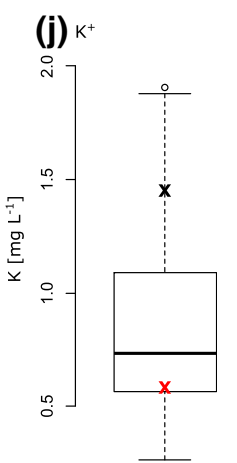

Fig. 3 Variation in water quality parameters across 43 sites in Brunei and Limbang Division, Malaysia (see inset of Fig. 1 for the location of sites). Values at the sites where Ctenodesma borneensis and Sinanodonta lauta were found are indicated by red and black crosses, respectively

The population was found based on the knowledge and guidance of a local Lun Bawang (an indigenous tribe of this region) and is located in a relatively pristine patch of secondary rainforest only accessible by hiking. The stream was small $(<2 \mathrm{~m}$ width) and shallow ( $<1 \mathrm{~m}$ depth), with a muddy substrate and abundant dead wood and leaf litter material (Fig. 2c), which was also recorded as high TP and OM concentrations in the water (Fig. 3). Other water chemistry parameters indicated good water quality with almost neutral $\mathrm{pH}$, and low conductivity, nutrients and $\mathrm{K}^{+}$concentrations (Fig. 3). Nevertheless, C. borneensis population density was low, as only three specimens were found over a 4-person hour survey time.

The only other population of freshwater mussels found in our surveys was that of Sinanodonta lauta in a pond in Lawas District, Limbang Division, about $2.5 \mathrm{~km}$ east of the border to Brunei (Fig. 1). Being morphologically very similar to the widespread $S$. cf. woodiana, this population was identified through DNA barcoding. COI sequences were generated for three specimens (Genbank Accession Numbers MN900791-93), all of which were identical and matched with Haplotype 54 of S. lauta (Lopes-Lima et al. 2020). The specimens had been intentionally introduced to the pond by the owner a few years before, who had bought them from a market in Lawas town. Density was very high and several dozen specimens were sampled within $15 \mathrm{~min}$. Water chemical parameters indicated 


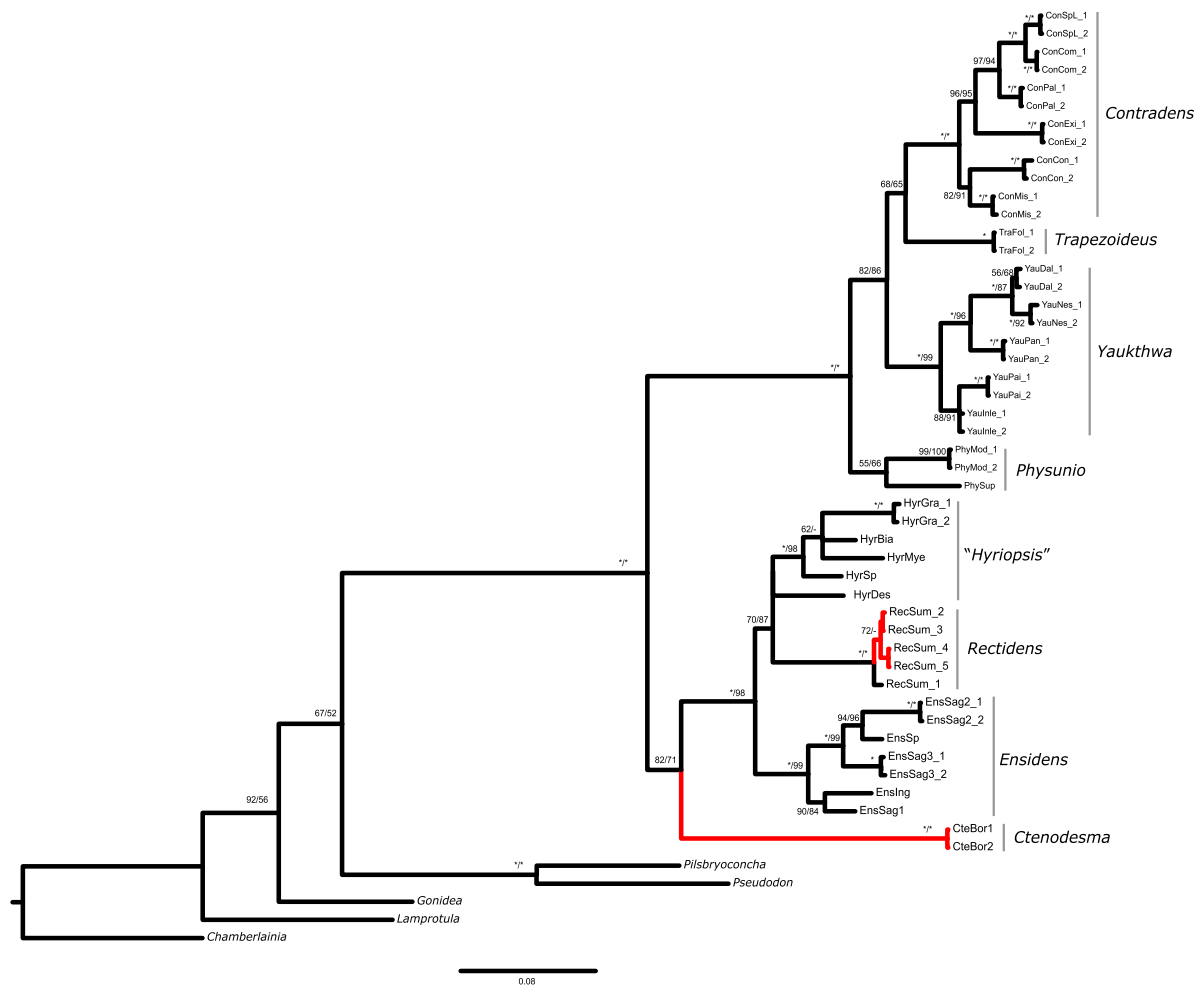

Fig. 4 Bayesian phylogenetic reconstruction $(\mathrm{COI}+28 \mathrm{~S})$ of the Gonideinae with support values listed as posterior probabilities / ultrafast bootstraps (PP/UF). Values of PP and UF $<50$ are marked with "- “; values of $\mathrm{PP}$ and $\mathrm{UF}=100$ are marked with “*”. Red branches indicate lineages sampled from Borneo

slightly elevated TAN and $\mathrm{K}^{+}$concentrations, and a water temperature of $>30{ }^{\circ} \mathrm{C}$ (Fig. 3).

Interviews at sites that could not be surveyed physically did not reveal any additional potential occurrences of mussels except for one anecdotal record of dense mussel populations in the upper Baram River basin in Gunung Mulu National Park (Fig. 1). Despite interviewing $>100$ people at 20 sites across Brunei, there was no indication of the presence of freshwater mussels in Brunei in the past or present.

\section{Phylogenetic position of Ctenodesma}

The most likely partitioning and modeling scheme was to treat all subsets (28S, COI_pos1, COI_pos2, COI_pos3) as separate partitions using the GTR + G model of nucleotide evolution. Convergence of the BI analysis was supported by the average standard deviation of split frequencies (0.001876), average PRSF values (1.000), and high ESS values ( $>$ 3000). The BI and ML reconstructions recovered identical supraspecific relationships except for a minor difference in the sister relationships with Hyriopsis (Fig. 4). Ctenodesma was recovered as sister to sampled representatives of the tribe Rectidentini 
(Hyriopsis, Rectidens and Ensidens), however, this clade had limited support (82 PP/72 UFBS).

\section{Discussion}

\section{Rediscovery, population status and phylogeny of Ctenodesma borneensis}

Our work has resulted in the first confirmation of a population of $C$. borneensis for 57 years. The species was first described in 1874 from Lake (Danau) Seriang (alternative spelling Siriang), Kapuas basin, West Kalimantan, Indonesia, and has a presumed native distribution covering West Kalimantan, Sarawak, and Sabah (Fig. 1; Table 1). To our knowledge, two museum lots exist from "Sarawak", dated from 1937 and 1945, respectively (Graf and Cummings 2019). The latest record is that by N.S. Haile from 1962 from Gomantong, Sandakan Residency, Sabah, Malaysia.

Although our find is certainly encouraging for freshwater mussel conservation, $C$. borneensis has likely declined in its area of occupancy and is now extremely rare, consisting of only isolated populations in the north and potentially other parts of Borneo. The population presented in this paper remains the only one we found across an area of 150,000 $\mathrm{km}^{2}$ and 115 sites that have been surveyed for freshwater mussels from 2016 to 2018 (Zieritz et al. 2018c) (Fig. 1). Furthermore, although several other sites in the immediate proximity of the site where $C$. borneensis was found were surveyed, no further populations could be found (inset of Fig. 1). Finally, the population density of the identified population was extremely low.

The reasons for the apparent decline of this species may be linked to the large-scale deforestation across Borneo. The fact that the only two populations of $C$. borneensis recorded by scientists in the past 60 years inhabit streams within dense rainforests (the second site being Gomantong, which has been a designated Protection Forest Reserve since 1984; UNEP-WCMC and IUCN 2014-2020) suggests that the species may be particularly sensitive to human pressures. The Limbang River is known for its geological complexity, and susceptibility to erosion and flash floods (Krishnan et al. 2017). Ongoing and expanding deforestation activities in this area (World Resources Institute 2014) may therefore pose a particular threat to the integrity of the potential habitats for $C$. borneensis and other freshwater taxa.

Our phylogenetic analyses for the first time include an endemic Bornean freshwater mussel genus, i.e. Ctenodesma, which revealed that this genus represents (part of) a highly distinct and previously unsampled molecular phylogenetic lineage (Fig. 4), thereby identifying it as a particularly valuable conservation target (Faith 1996). Specifically, Ctenodesma was recovered as the sister-group to the Rectidentini and exhibited morphological characteristics typical of this tribe, including tetragenous marsupia (Lopes-Lima et al. 2017). Of the three Rectidentini genera sequenced to date, Ensidens and Hyriopsis are distributed across SE-Asia, whilst Rectidens is restricted to Sundaland (i.e. Java, Sumatra, Peninsular Malaysia and Borneo) (Graf and Cummings 2019). The non-monophyly of the Borneo samples included in our analysis (Rectidens and Ctenodesma) suggest multiple lineages have colonised Borneo, and appear to have done so by different mode and tempo. Rectidens appears to have more recently and more completely dispersed across Sundaland, whereas Ctenodesma appears to represent a relatively older colonisation event. Several other Sundaland endemics have been hypothesised to belong to various clades of the subfamily Gonideinae, including Caudiculatus (Chamberlainini), Elongaria and 
Prohyriopsis (Rectidentini), and Pressidens (Contradentini) (Graf and Cummings 2019; Pfeiffer et al. 2019); however, these taxa have yet to be included in a molecular phylogenetic reconstruction. The inclusion of these phylogenetically unsampled lineages will be useful in more completely estimating the evolutionary and biogeographic history of the freshwater mussels of Sundaland. Improved sampling of the Bornean and greater Sundaland fauna will also elucidate whether the recovered long branch of Ctenodesma represents a relict and depauperate lineage or a more diverse, but currently undersampled, radiation.

\section{Introduction of non-native freshwater mussels}

Whilst native mussels are likely declining in northern Borneo, our study revealed the introduction of a second non-native freshwater mussel species (in addition to $S$. cf. woodiana) to this island, i.e. S. lauta. The population from a pond in Limbang Division represents the first record of this species outside its native distribution in Japan, Korea and Southeast Russia (Lopes-Lima et al. 2020). This species is distinct but closely related to $S$. cf. woodiana, native to the Yangtze basin, which is actively spread, repeatedly introduced and very common in Sabah, and is also present in the Suai basin, Sarawak (Zieritz et al. 2018c; Lopes-Lima et al. 2020). The main vectors for ongoing introductions and spread of Sinanodonta in Borneo is indirect through fish that are infected with mussel larvae, which live as ectoparasites on fish gills and fins (Wächtler et al. 2001), as well as direct and intentional spread by humans for ornamental purposes and as a food source (Zieritz et al. 2018 c). Introductions appear to be usually confined to ponds or other man-made water bodies, where native species are unable to survive and reproduce. As such, the current threat posed by non-native freshwater mussels to the native mussel fauna of Borneo appears to be small when compared to the scale of destruction posed by ongoing logging activities across the island (Miettinen et al. 2011).

\section{Status of northern Borneo's mussels in general}

Based on the combined dataset from our previous (Zieritz et al. 2018c) and present work, the current situation of northern Borneo's freshwater mussel fauna is very concerning. As discussed in detail by Zieritz et al. (2018c), historical records indicate the native distribution of five species within the boundaries of the area spanning from the Rajang basin in the west to the upper Sembakung, Kinabatangan and Bengkoka basins to the east, i.e. $C$. borneensis, P. exanthematicus, Pseudodon walpolei, R. sumatrensis and Schepmania niewenhuisi. Of these, only $R$. sumatrensis appears to occur in healthy population sizes across several river basins of central Sarawak. Whilst $C$. borneensis has now been confirmed from a single site in the Limbang basin, and $S$. niewenhuisi was relatively recently (i.e. in 2000) collected from Sabah (albeit as dead shells only), $P$. exanthematicus and $P$. walpolei have not been found for at least 50 years. The fact that historical records of these two species are largely confined to the area already surveyed by us indicates that they are very rare or potentially already extinct. Future surveys across Borneo will be needed to revalidate this statement and identify any remaining populations of these endemic Bornean mussel species. Currently available data suggest that endemic Bornean mussels can only sustain populations in relatively pristine habitats. Future surveys targeted towards these species should thus focus on protected areas of northern Borneo, including Labi Hills (Sungai Ingei Conservation) in Brunei Darussalam, Gunung Mulu, Gunung Buda, Pulong Tau, Usun Apau and Lanjak Entimau in Sarawak. Remaining populations of Bornean 
endemic mussel species in unprotected areas would benefit from retaining or re-establishing riparian buffer zones, which have been shown to be effective in protecting freshwater ecosystems and biodiversity (Luke et al. 2017a, b). Although legislation guidelines in Sarawak state a buffer zone of 5-50 m along all rivers depending on river width, current implementation rate is poor, as non-compliance with these guidelines has limited to no legal consequences (Ligtermoet et al. 2009; Luke et al. 2019).

Acknowledgements This study was funded by the Rufford Foundation (Small Grant 23152-1 to AZ). In Malaysia, fieldwork was carried out under permits number (15)JHS/NCCD/600-7/2/107 by the Forest Department Sarawak. In Brunei Darussalam, permissions to carry out fieldwork and collect samples were given by the Department of Forestry (197/JPH/UND/17PT.1 and JPH/PDK/01 pt2) and Department of Museums (JMB/1029/97/6), whereas export permits were provided by the Biodiversity and Innovation Centre (BioRIC/HOB/TAD/51). MLL was supported by FCT-Fundação para a Ciência e a Tecnologia (SFRH/BD/115728/2016). We thank the Institute for Biodiversity and Environmental Research, Brunei, for their assistance in obtaining permits and T Needham for conducting ion analyses.

Open Access This article is licensed under a Creative Commons Attribution 4.0 International License, which permits use, sharing, adaptation, distribution and reproduction in any medium or format, as long as you give appropriate credit to the original author(s) and the source, provide a link to the Creative Commons licence, and indicate if changes were made. The images or other third party material in this article are included in the article's Creative Commons licence, unless indicated otherwise in a credit line to the material. If material is not included in the article's Creative Commons licence and your intended use is not permitted by statutory regulation or exceeds the permitted use, you will need to obtain permission directly from the copyright holder. To view a copy of this licence, visit http://creativecommons.org/licenses/by/4.0/.

Author contributions AZ developed the study, conducted fieldwork, laboratory work, parts of the analyses and led the writing. KWS conducted molecular analyses. HT and KAR planned and conducted fieldwork, and assisted with morphological analysis. JP and MLL conducted fieldwork and phylogenetic analyses. SM contributed to laboratory analyses. ZS advised on fieldwork planning. All authors contributed to writing.

\section{References}

Abell R, Thieme ML, Revenga C, Bryer M, Kottelat M, Bogutskaya N, Coad B, Mandrak N, Balderas SC, Bussing W, Stiassny MLJ, Skelton P, Allen GR, Unmack P, Naseka A, Ng R, Sindorf N, Robertson J, Armijo E, Higgins JV, Heibel TJ, Wikramanayake E, Olson D, López HL, Reis RE, Lundberg JG, Sabaj Pérez MH, Petry P (2008) Freshwater ecoregions of the world: a new map of biogeographic units for freshwater biodiversity conservation. Bioscience 58:403-414. https://doi.org/10.1641/b580507

Brook BW, Sodhi NS, Ng PKL (2003) Catastrophic extinctions follow deforestation in Singapore. Nature 424:420-423. https://doi.org/10.1038/nature01795

Bryan JE, Shearman PL, Asner GP, Knapp DE, Aoro G, Lokes B (2013) Extreme differences in forest degradation in Borneo: comparing practices in Sarawak, Sabah, and Brunei. PLoS ONE 8:e69679. https://doi.org/10.1371/journal.pone.0069679

Chowdhury GW, Zieritz A, Aldridge DC (2016) Ecosystem engineering by mussels supports biodiversity and water clarity in a heavily polluted lake in Dhaka, Bangladesh. Freshw Sci 35:188-199. https://doi. org/10.1086/684169

Dudgeon D, Arthington AH, Gessner MO, Kawabata Z, Knowler D, Lévêque C, Naiman RJ, Prieur-Richard AH, Soto D, Stiassny MLJ, Sullivan CA (2006) Freshwater biodiversity: importance, status, and conservation challenges. Biol Rev 81:163-182

Faith DP (1996) Conservation priorities and phylogenetic pattern. Conserv Biol 10:1286-1289

Gaveau DLA, Sloan S, Molidena E, Yaen H, Sheil D, Abram NK, Ancrenaz M, Nasi R, Quinones M, Wielaard N, Meijaard E (2014) Four decades of forest persistence, clearance and logging on Borneo. PLoS ONE 9:e101654. https://doi.org/10.1371/journal.pone.0101654 
Graf DL, Cummings KS (2019) The Freshwater Mussels (Unionoida) of the World (and other less consequential bivalves), updated 15 May 2019. MUSSEL Project Web Site. https://mussel-project.uwsp. edu/fmuotwaolcb/unionidae.html. Accessed May 2019

Haas F (1969) Superfamilia Unionacea. In: Mertens R, Henning W (eds) Das Tierreich (Berlin). de Gruyter \& Co., Berlin, pp 1-663

Huelsenbeck JP, Ronquist F (2001) MRBAYES: Bayesian inference of phylogenetic trees. Bioinformatics 17:754-755. https://doi.org/10.1093/bioinformatics/17.8.754

IUCN (2019) The IUCN Red List of Threatened Species. Version 2019-1. https://www.iucnredlist. org. Accessed May 2019

Iwata T, Nakano S, Inoue M (2003) Impacts of past riparian deforestation on stream communities in a tropical rain forest in Borneo. Ecol Appl 13:461-473

Krishnan MVN, Prasanna MV, Vijith H (2017) Optimisation of morphometric parameters of Limbang river basin, Borneo in the equatorial tropics for terrain characterisation. Model Earth Syst Environ 3:1477-1490. https://doi.org/10.1007/s40808-017-0394-9

Kumar S, Stecher G, Li M, Knyaz C, Tamura K (2018) MEGA X: molecular evolutionary genetics analysis across computing platforms. Mol Biol Evol 35:1547-1549. https://doi.org/10.1093/molbev/msy096

Lanfear R, Calcott B, Ho SY, Guindon S (2012) Partitionfinder: combined selection of partitioning schemes and substitution models for phylogenetic analyses. Mol Biol Evol 29:1695-1701. https://doi.org/10. 1093/molbev/mss020

Lanfear R, Frandsen PB, Wright AM, Senfeld T, Calcott B (2017) PartitionFinder 2: new methods for selecting partitioned models of evolution for molecular and morphological phylogenetic analyses. Mol Biol Evol 34:772-773. https://doi.org/10.1093/molbev/msw260

Larkin MA, Blackshields G, Brown NP, Chenna R, McGettigan PA, McWilliam H, Valentin F, Wallace IM, Wilm A, Lopez R, Thompson JD, Gibson TJ, Higgins DG (2007) Clustal W and Clustal X version 2.0. Bioinformatics 23:2947-2948. https://doi.org/10.1093/bioinformatics/btm404

Ligtermoet E, Chambers JM, Kobryn HT, Davis J (2009) Determining the extent and condition of riparian zones in drinking water supply catchments in Sarawak, Malaysia. Water Supply 9:517-531. https://doi. org/10.2166/ws.2009.580

Lopes-Lima M, Burlakova LE, Karatayev AY, Mehler K, Seddon M, Sousa R (2018) Conservation of freshwater bivalves at the global scale: diversity, threats and research needs. Hydrobiologia 810:1-14. https://doi.org/10.1007/s10750-017-3486-7

Lopes-Lima M, Froufe E, Do VT, Ghamizi M, Mock KE, Kebapçı Ü, Klishko O, Kovitvadhi S, Kovitvadhi U, Paulo OS, Pfeiffer JM, Raley M, Riccardi N, Şereflişan H, Sousa R, Teixeira A, Varandas S, Wu X, Zanatta DT, Zieritz A, Bogan AE (2017) Phylogeny of the most species-rich freshwater bivalve family (Bivalvia: Unionida: Unionidae): defining modern subfamilies and tribes. Mol Phylogenet Evol 106:174-191. https://doi.org/10.1016/j.ympev.2016.08.021

Lopes-Lima M, Hattori A, Kondo T, Lee JH, Kim SK, Shirai A, Hayashi H, Usui T, Sakuma K, Toriya T, Sunamura Y, Ishikawa H, Hoshino N, Kusano Y, Kumaki H, Tanaka A, Sao K, Sano I, Miyazaki J-I, Gonçalves D, Klishko O, Konopleva E, Vikhrev I, Kondakov AV, Gofarov MY, Bolotov I, Zieritz A, Bogan AE, Froufe E (2020) Freshwater mussels (Bivalvia: Unionidae) from the Rising Sun (Far East Asia): phylogeny, systematics and distribution. Mol Phylogenet Evol 146:106755. https://doi.org/10. 1016/j.ympev.2020.106755

Lorenzen CJ (1967) Determination of chlorophyll and pheo-pigments: spectrophotometric equations. Limn Oceanogr 12:343-346. https://doi.org/10.4319/lo.1967.12.2.0343

Luke SH, Barclay H, Bidin K, Vun Khen C, Ewers RM, Foster WA, Nainar A, Pfeifer M, Reynolds G, Turner EC, Walsh RPD, Aldridge DC (2017a) The effects of catchment and riparian forest quality on stream environmental conditions across a tropical rainforest and oil palm landscape in Malaysian Borneo. Ecohydrology 10:e1827. https://doi.org/10.1002/eco.1827

Luke SH, Dow RA, Butler S, Vun Khen C, Aldridge DC, Foster WA, Turner EC (2017b) The impacts of habitat disturbance on adult and larval dragonflies (Odonata) in rainforest streams in Sabah, Malaysian Borneo. Freshw Biol 62:491-506

Luke SH, Slade EM, Gray CL, Annammala KV, Drewer J, Williamson J, Agama AL, Ationg M, Mitchell SL, Vairappan CS, Struebig MJ (2019) Riparian buffers in tropical agriculture: scientific support, effectiveness and directions for policy. J Appl Ecol 56:85-92. https://doi.org/10.1111/1365-2664. 13280

Mackereth FJH, Heron J, Talling JF (1989) Water analysis: some revised methods for limnologists. Freshwater Biological Association Special Publication, Ambleside

Mathew MJ, Menier D, Siddiqui N, Ramkumar M, Santosh M, Kumar S, Hassaan M (2016) Drainage basin and topographic analysis of a tropical landscape: Insights into surface and tectonic processes in northern Borneo. J Asian Earth Sci 124:14-27. https://doi.org/10.1016/j.jseaes.2016.04.016 
Miettinen J, Shi C, Liew SC (2011) Deforestation rates in insular Southeast Asia between 2000 and 2010. Glob Change Biol 17:2261-2270. https://doi.org/10.1111/j.1365-2486.2011.02398.x

Myers N, Mittermeier RA, Mittermeier CG, da Fonseca GAB, Kent J (2000) Biodiversity hotspots for conservation priorities. Nature 403:853-858. https://doi.org/10.1038/35002501

Nguyen LT, Schmidt HA, von Haeseler A, Minh BQ (2015) IQ-TREE: a fast and effective stochastic algorithm for estimating maximum-likelihood phylogenies. Mol Biol Evol 32:268-274. https://doi.org/ 10.1093/molbev/msu300

Pfeiffer JM, Breinholt JW, Page LM (2019) Unioverse: A phylogenomic resource for reconstructing the evolution of freshwater mussels (Bivalvia, Unionoida). Mol Phylogenet Evol 137:114-126. https://doi. org/10.1016/j.ympev.2019.02.016

Rahim KA (2012) Diversity, Ecology and Distribution of Non-Indigenous Freshwater Fish in Malaysia. PhD thesis, Universiti Putra Malaysia

Ronquist F, Teslenko M, van der Mark P, Ayres DL, Darling A, Höhna S, Larget B, Liu L, Suchard MA, Huelsenbeck JP (2012) MrBayes 3.2: efficient Bayesian phylogenetic inference and model choice across a large model space. Syst Biol 61:539-542. https://doi.org/10.1093/sysbio/sys029

Sulaiman Z, Hui TH, Lim KKP (2018) Annotated checklist of freshwater fishes from Brunei Darussalam, Borneo. Zootaxa 4379:24-46

UNEP-WCMC, IUCN (2014-2020) Protected Planet: The World Database on Protected Areas (WDPA). https://www.protectedplanet.net/. Accessed May 2019

Vaughn CC (2018) Ecosystem services provided by freshwater mussels. Hydrobiologia 810:15-27

Wächtler K, Mansur MCD, Richter T (2001) Larval types and early postlarval biology in naiads (Unionoida). In: Bauer G, Wächtler K (eds) Ecology and evolution of the freshwater mussels Unionoida. Springer, Berlin, pp 93-125

World Resources Institute (2014) Global Forest Watch. www.globalforestwatch.org. Accessed May 2019

Zieritz A, Azam-Ali S, Marriott AL, Nasir NABM, Ng QN, Razak NAABA, Watts M (2018a) Biochemical composition of freshwater mussels in Malaysia: A neglected nutrient source for rural communities. J Food Compos Anal 72:104-114. https://doi.org/10.1016/j.jfca.2018.06.012

Zieritz A, Bogan AE, Froufe E, Klishko O, Kondo T, Kovitvadhi U, Kovitvadhi S, Lee JH, Lopes-Lima M, Pfeiffer JM, Sousa R, van Do T, Vikhrev I, Zanatta DT (2018b) Diversity, biogeography and conservation of freshwater mussels (Bivalvia: Unionida) in East and Southeast Asia. Hydrobiologia 810:29-44. https://doi.org/10.1007/s10750-017-3104-8

Zieritz A, Bogan AE, Rahim KAA, Sousa R, Jainih L, Harun S, Razak NFA, Gallardo B, McGowan S, Hassan R, Lopes-Lima M (2018c) Changes and drivers of freshwater mussel diversity and distribution in northern Borneo. Biol Cons 219:126-137. https://doi.org/10.1016/j.biocon.2018.01.012

Zieritz A, Lopes-Lima M (2018) Handbook and National Red-List of the Freshwater Mussels of Malaysia. pp 1-28. https://www.nationalredlist.org/handbook-and-national-red-list-of-freshwater-mussels-ofmalaysia/. Accessed May 2019

Zieritz A, Lopes-Lima M, Bogan AE, Sousa R, Walton S, Rahim KAA, Wilson J-J, Ng P-Y, Froufe E, McGowan S (2016) Factors driving changes in freshwater mussel (Bivalvia, Unionida) diversity and distribution in Peninsular Malaysia. Sci Total Environ 571:1069-1078. https://doi.org/10.1016/j. scitotenv.2016.07.098

Zieritz A, Mahadzir FN, Chan WN, McGowan S (2019) Effects of mussels on nutrient cycling and bioseston in two contrasting tropical freshwater habitats. Hydrobiologia 835:179-191. https://doi.org/10.1007/ s10750-019-3937-4

Publisher's Note Springer Nature remains neutral with regard to jurisdictional claims in published maps and institutional affiliations. 


\section{Affiliations}

\section{Alexandra Zieritz ${ }^{1,2}$ (D) Hussein Taha ${ }^{3} \cdot$ Manuel Lopes-Lima $^{4}$ (D) John Pfeiffer ${ }^{5}$ (D) Kong Wah Sing ${ }^{2} \cdot$ Zohrah Sulaiman $^{3,6} \cdot$ Suzanne McGowan $^{1}$ Khairul Adha A.Rahim 7,8}

$\bowtie$ Alexandra Zieritz

alexandra.zieritz@nottingham.ac.uk

1 School of Geography, University of Nottingham, University Campus, Nottingham NG7 2RD, UK

2 School of Environmental and Geographical Sciences, University of Nottingham Malaysia Campus, Jalan Broga, 43500 Semenyih, Malaysia

3 Environmental and Life Sciences Programme, Faculty of Science, Universiti Brunei Darussalam, Jalan Tungku Link, Bandar Seri Begawan BE1410, Brunei Darussalam

4 CIBIO/InBIO - Research Center in Biodiversity and Genetic Resources, University of Porto, Campus Agrário de Vairão, 4485-661 Vairão, Portugal

5 National Museum of Natural History, Smithsonian Institution, Washington, DC, USA

6 Universiti Teknologi Brunei, Jalan Tungku Link, Bandar Seri Begawan BE1410, Brunei Darussalam

7 Faculty of Resource Science \& Technology, Universiti Malaysia Sarawak, 94300 Kota Samarahan, Sarawak, Malaysia

8 Institute of Tropical Biodiversity and Sustainable Development,, Universiti Malaysia Terengganu, 21030 Kuala Terengganu, Terengganu, Malaysia 